\title{
Changes in the expression of neurohypophyseal prolactins during the estrous cycle and after estrogen treatment
}

\author{
L Torner, G Nava, Z Dueñas, A Corbacho, S Mejía, F López, \\ M Cajero, G Martínez de la Escalera and C Clapp \\ Centro de Neurobiología, Universidad Nacional Autónoma de México, 76001 Querétaro, Qro, México \\ (Requests for offprints should be addressed to C Clapp, Centro de Neurobiología, Universidad Nacional Autónoma de México, Apdo. Postal 1-1141, \\ 76001 Querétaro, Qro, México) \\ (Z Dueñas is now at Fundación Universitaria de Boyacá, Tunja, Colombia)
}

\begin{abstract}
Estrogens are recognized regulators of the expression of neurohypophyseal hormones and of anterior pituitary prolactin (PRL). Here we have investigated whether the levels of PRL mRNA and of 23 and $14 \mathrm{kDa}$ PRL variants present in the hypothalamo-neurohypophyseal system change during the estrous cycle or in response to estrogen treatment. The reverse transcription polymerase chain reaction (RT-PCR) was performed to examine PRL mRNA expression in isolated paraventricular (PVN) and supraoptic (SON) hypothalamic nuclei. In both nuclei PRL mRNA levels appeared higher in cycling females than in male rats, with the highest level occurring at estrus. This increase may involve estrogen action, since estrogen administration to ovariectomized rats was associated with apparently higher PRL mRNA levels in both the PVN and SON. Expression of the PRL gene at these sites may occur via both transcriptional factor Pit-1-dependent and -independent mechanisms. RT-PCR detected the
\end{abstract}

mRNA for Pit-1 in the PVN but only at estrus. The concentration of the $23 \mathrm{kDa}$ immunoreactive PRL determined in the neurohypophysis was significantly higher during estrus and after estrogen treatment. However, no difference was detected in the levels of the neurohypophyseal $14 \mathrm{kDa}$ PRL-like fragment along the estrous cycle nor after estrogen administration. This lack of parallelism between neurohypophyseal PRLs could relate to an estrogen-induced inhibition of the proteolysis of $23 \mathrm{kDa}$ PRL at this site, since estrogen treatment reduced the activity of neurohypophyseal proteolytic enzymes able to cleave PRL. Altogether our results are consistent with estrogens having a stimulatory effect on PRL gene expression in the hypothalamo-neurohypophyseal system and a concomitant inhibitory action on PRL proteolysis at this site.

Journal of Endocrinology (1999) 161, 423-432

\section{Introduction}

The hypothalamic paraventricular (PVN) and supraoptic (SON) nuclei contain magnocellular neurosecretory neurons that synthesize vasopressin and oxytocin. These two peptide hormones are, after axonal transport and storage, released from nerve endings in the posterior pituitary into the systemic circulation to control fluid balance and smooth muscle contractility (Hatton 1990). Apart from vasopressin and oxytocin, magnocellular neurons of the PVN and SON synthesize and store several other chemical messengers. For example, vasopressin neurons have been shown to contain galanin, dynorphin, angiotensin II, enkephalin peptide, histidine isoleucine/ vasoactive intestinal polypeptide; whereas oxytocin neurons contain cholecystokinin, corticotropin-releasing factor, thyrotropin releasing hormone, enkephalin, etc. (Brownstein \& Mezey 1986, Villar et al. 1990, Meister 1993).
Recent evidence has suggested that prolactins (PRLs) are included among the neuropeptides expressed by magnocellular PVN and SON neurohypophyseal cells (Clapp et al. 1994). PRL mRNA was identified in isolated PVN by the reverse transcription-polymerase chain reaction (RT-PCR), and PRL proteins of 23 and $14 \mathrm{kDa}$ were detected within both the PVN and SON and in their axonal projections into the neurohypophysis (Clapp et al. 1994). These PRLs were localized within secretory granules of vasopressin-containing cells (Mejía et al. 1997).

The importance of PRLs being colocalized with the classical neurohypophyseal hormones, as for the other neuropeptides, remains unclear. Local interactions at the pituitary level and effects on peripheral tissues, via their systemic release, are current possibilities (Brownstein \& Mezey 1986, Hatton 1990, Villar et al. 1990, Meister 1993). In this regard, PRLs were found to be released from neurohypophyseal endings in response to high 
potassium and the $14 \mathrm{kDa}$ variant was found in the circulation (Torner et al. 1995). Moreover the kidney is a well-known target of neurohypophyseal hormones and of PRL (Hebert et al. 1981, Loretz \& Bern 1982) and PRL fragments have been shown to bind to renal PRL receptors with higher affinity than PRL itself (Clapp et al. 1989).

Regulatory mechanisms affecting vasopressin and/or oxytocin may also affect neurohypophyseal PRLs. Estrogens appear to be common regulators for neurohypophyseal hormones and for PRL. Magnocellular neurons of the PVN and SON express nuclear estrogen receptors (Simerly et al. 1990, Alves et al. 1998), and estrogen has been shown to stimulate the release of both neurohormones (Slowsky et al. 1979, Yamaguchi et al. 1979, Wang et al. 1995). The neurohypophyseal levels of both vasopressin and oxytocin have been found to change over the course of the estrous cycle or in response to estrogenic treatment (Crowley et al. 1978). Also, peptides colocalized with vasopressin showed evidence of enhanced expression in the presence of estrogens (Levin \& Sawchenko 1993). On the other hand, estrogens are known to stimulate PRL gene expression in the anterior pituitary gland, as well as in the brain (Ben-Jonathan et al. 1996). An estrogen response element is located in the distal enhancer region of the PRL gene (Maurer et al. 1990). Hypothalamic PRL levels are higher in females than in male rats and estrogen increases PRL gene expression and PRL release by the hypothalamus of hypophysectomized rats (DeVito 1988, DeVito et al. 1991, 1992).

In the present study we have investigated whether estrogen could affect the expression of PRL mRNA and the concentration of PRL proteins in the hypothalamoneurohypophyseal system. Furthermore, it is known that to exert their actions, estrogens require multiple Pit-1 binding sites (Nowakowski \& Maurer 1994). Pit-1 is a POU homeodomain transactivating factor essential for tissue-specific expression of the PRL gene in the anterior pituitary gland (Ingraham et al. 1988, Nelson et al. 1988, Crenshaw et al. 1989). Therefore we have also examined whether Pit-1 is coexpressed with the PRL gene in the hypothalamo-neurohypophyseal system.

\section{Materials and Methods}

\section{Animals}

Virgin prepuberal female (15 days old) and adult male and female $(180-250 \mathrm{~g})$ Wistar rats were maintained under conditions of controlled temperature $\left(22-24^{\circ} \mathrm{C}\right)$ and lighting (lights on from 0600 to $1800 \mathrm{~h}$ ). They had free access to food and water. In a group of adult females, estrous cyclicity was monitored by daily cytological examination. Rats with at least three consecutive 4 day estrous cycles were killed by decapitation at $1100-1200 \mathrm{~h}$ on estrus, diestrus II and proestrus. In the other group, adult rats were bilaterally ovariectomized (OVX) under sodium pentobarbital anesthesia and implanted or not with estradiol benzoate. Implants were subcutaneous and consisted of slow-releasing capsules made of silastic tubing filled with estradiol crystals and sealed with silastic cement. Ten days after surgery, OVX and OVX/estradiol-treated rats were killed by decapitation. Brains and hypophyseal glands were quickly removed. The hypophysealneurointermediate lobe was carefully separated from the anterior lobe under a dissecting microscope. Tissues were immediately frozen in dry ice and stored at $-70{ }^{\circ} \mathrm{C}$.

\section{RNA isolation}

Forty PVN and 40 SON per experimental group were isolated from frozen brain slices $(0.5 \mathrm{~mm}$ thick) by the micropunching technique (Palkovits 1983). Total RNA was extracted from PVN, SON, cerebral cortex and anterior pituitary according to the guanidinium thiocyanate-phenol-chloroform procedure (Chomczynski \& Sacchi 1987).

\section{$R T-P C R$}

Two primers complementary to rat PRL cDNA were used: upstream primer rPRL-5' (5'-TGTTCTGGT GGCGACTGCCAGACACCT- $3^{\prime}$ ) from exon 2 and downstream primer rPRL-3' (5'-TATCTTTTCGAT $^{\prime}$ CCCTTCGAGAAGCCG-3') from exon 4. For the full size PRL mRNA, this primer combination should generate a product of $388 \mathrm{bp}$. The Pit-1 mRNA was amplified using $5^{\prime}$ primer (5'-CTCGGCTGATACCTTTATA-3') and $3^{\prime}$ primer $\left(5^{\prime}\right.$-TTCCTTTCGTTTGCTCCCA- $\left.3^{\prime}\right)$. This combination of primers should yield an amplification product of $701 \mathrm{bp}$. Amplification efficiency was corrected using the amplification of $\beta$-actin mRNA. The $\beta$-actin primers were: the $5^{\prime}$ primer Act- $5^{\prime}$ (5'-ATGGTGGGAA TGGGTCAGAA- $\left.3^{\prime}\right)$ and the $3^{\prime}$ primer Act- $3^{\prime}$ (5'-TC GTACTCCTGCTTGCTGA- $\left.3^{\prime}\right)$. The $\beta$ - actin PCR should generate a $876 \mathrm{bp}$ product.

One and a half micrograms total RNA were reverse transcribed for $1 \mathrm{~h}$ at $37^{\circ} \mathrm{C}$ in $24 \mu \mathrm{l}$ containing $20 \mathrm{mM}$ Tris- $\mathrm{HCl} \quad(\mathrm{pH} \quad 8 \cdot 3), \quad 50 \mathrm{mM} \mathrm{KCl}, 2.5 \mathrm{mM} \mathrm{MgCl}_{2}$, $0.2 \mathrm{mM}$ each dNTP, $600 \mathrm{ng}$ oligo (dT) primer, 5 units RNasin (Promega, Madison, WI, USA), and 200 units of reverse transcriptase (RT) (Moloney murine leukemia virus). After incubation, the RT mixture was heated at $96{ }^{\circ} \mathrm{C}$ for $5 \mathrm{~min}$ and chilled on ice. Three microliters of the $\mathrm{RT}$ reaction mixture were added to the PCR mixture in $20 \mu$ containing $20 \mathrm{mM}$ Tris- $\mathrm{HCl}$ (pH 8.3), $50 \mathrm{mM} \mathrm{KCl}$, $2 \mathrm{mM} \mathrm{MgCl} 2,200 \mu \mathrm{M}$ each dNTP, $400 \mathrm{nM}$ of each primer and 1 unit of Taq DNA polymerase. After denaturation at $94{ }^{\circ} \mathrm{C}$ for $3 \mathrm{~min}$, amplification of PRL cDNA was performed for 40 cycles $\left(94^{\circ} \mathrm{C}\right.$ for $30 \mathrm{~s}, 65^{\circ} \mathrm{C}$ for $45 \mathrm{~s}$ and $72{ }^{\circ} \mathrm{C}$ for $45 \mathrm{~s}$ ) followed by $72{ }^{\circ} \mathrm{C}$ for $7 \mathrm{~min}$ at the end 
of the amplification. For actin and Pit-1 the 40 cycle amplification used an annealing temperature of $55^{\circ} \mathrm{C}$.

In order to ensure that the 40 cycle amplification was in the linear range, PCR titrations were carried out using serial 2- to 10-fold dilutions of PRL and $\beta$-actin cDNA amplified from PVN and SON samples. As an attempt to normalize contaminations of any type, tissue processing was performed in parallel, under identical conditions and from equal amounts of tissue. Nevertheless, contamination with genomic DNA, in amounts that could compete for primers, cannot be ruled out.

\section{Southern blot analysis}

Total RT-PCR reaction was loaded on a $1 \cdot 2 \%$ agarose gel and blotted onto Hybond-N membranes (Amersham International, Amersham, Bucks, UK). Membranes were hybridized with rat PRL cDNA (generously supplied by R Maurer, Oregon Health Sciences University, Portland, OR, USA), human Pit-1 cDNA (kindly provided by $\mathrm{H}$ Ingraham, University of California, San Francisco, CA, USA), and the 876 bp $\beta$-actin RT-PCR amplified product. Probes were labeled by random primer using $\left[{ }^{32}\right.$ P]dATP (Feimberg \& Vogelstein 1983). Hybridization was at $68{ }^{\circ} \mathrm{C}$ for $16 \mathrm{~h}$ in a solution containing $5 \times \mathrm{SSC}$

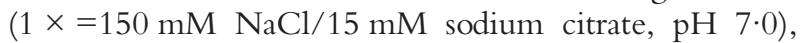
$0.5 \%$ SDS, $6 \times$ Denhardt's solution, and salmon sperm DNA at $100 \mu \mathrm{g} / \mathrm{ml}$. Blots were washed twice at room temperature with $2 \times$ SSC and $0 \cdot 1 \%$ SDS, three times at $68{ }^{\circ} \mathrm{C}$ with $0 \cdot 1 \times$ SSC and $0 \cdot 1 \%$ SDS, and then exposed to Kodak XAR-5 film. PRL and $\beta$-actin RT-PCR products were measured using densitometry. Various exposure times were followed to ensure that estimation of PRL and $\beta$-actin ratios were not influenced by saturated autoradiographic densitometric determinations.

\section{Western blot analysis}

Neurointermediate lobes ( $5 \mathrm{mg}$ ) were sonicated in $100 \mu \mathrm{l}$ lysis buffer $(0 \cdot 01 \mathrm{M}$ Tris- $\mathrm{HCl} / 0 \cdot 14 \mathrm{M} \mathrm{NaCl} / 1 \%$ Triton $\mathrm{X}-100, \mathrm{pH} 8 \cdot 0$, with aprotinin at $0 \cdot 2 \mathrm{U} / \mathrm{ml}$ and $1 \mathrm{mM}$ phenylmethylsulfonyl fluoride). Tissue extracts, corrected for their protein concentration, were subjected to reducing SDS-PAGE, and the proteins were blotted onto nitrocellulose membranes and probed with a 1:500 dilution of a $16 \mathrm{kDa}$ PRL antiserum and developed by using the alkaline phosphatase second antibody kit (Bio-Rad Labs, Hercules, CA, USA), as described (Torner et al. 1995). Intermediate hypophyseal lobes have been previously determined to be devoid of immunoreactive PRL (Clapp et al. 1994) and should not interfere with detection of PRLs in the neural lobe. The $16 \mathrm{kDa}$ PRL antiserum is specific for PRLs and has no cross-reactivity with vasopressin, oxytocin, neurophysins I and II, angiotensin II, $\beta$-lipoprotein, $\beta$-endorphin, met-enkephalin and adrenocorticotropin (residues 1-39) (Clapp et al. 1994). A linear relationship was observed between optical density values of PRL bands and serial protein concentrations of neurohypophyseal extracts. Likewise, linear standard curves were found for the PRL $23 \mathrm{kDa}$ standard or the $16 \mathrm{kDa}$ standard. Linear portions of all curves exhibited similar slopes, indicating that optical density values were indicative of PRL protein concentration.

\section{Analysis of PRL-cleaving activity}

The reported procedure with the following modifications was used (Clapp et al. 1987). Briefly, neurointermediate lobes were homogenized in cold $0 \cdot 1 \mathrm{M}$ Tris $-\mathrm{HCl} / 0 \cdot 25 \mathrm{M}$ sucrose $(\mathrm{pH} 7 \cdot 4 ; 1 \mu \mathrm{g} / 50 \mu \mathrm{l})$ and microfuged $(14000 \mathrm{~g})$ for $10 \mathrm{~min}$ at $4{ }^{\circ} \mathrm{C}$. The resulting pellet was resuspended in 0.1 M Tris- $\mathrm{HCl}$ ( $\mathrm{pH} 7 \cdot 4)$. Two micrograms rat PRL (B6; National Hormone and Pituitary Program, National Institute of Diabetes and Digestive and Kidney Disease, Bethesda, MD, USA) were incubated with various amounts of the pellet protein in $40 \mu \mathrm{l}$ reaction mixture $(0 \cdot 1 \mathrm{M}$ citrate-phosphate, $0.15 \mathrm{M} \mathrm{NaCl}, \mathrm{pH} \mathrm{3.3)}$ for $3 \mathrm{~h}$ at $37^{\circ} \mathrm{C}$ and the PRL cleavage products were determined by reducing SDS-PAGE. Kinetic studies using neurohypophyseal extracts from OVX rats were initially performed to determine the linear range of the assay. Within this range, three protein concentrations were selected that would help detection of putative estrogen effects on enzymatic activity in either direction (inhibition or augmentation).

\section{Analysis of data}

The optical densities of the autoradiographic signals or stained bands from Southern blots, Western blots or Coomassie-stained gels were determined using the Collage Image Analysis System (Fotodyne, Inc., New Berlin, WI, USA). Statistical analysis of the data was performed by ANOVA followed by Student's $t$-test (to determine if $P<0 \cdot 05)$.

\section{Results}

\section{PRL $m R N A$}

Total RNA prepared from a pool of isolated PVN or SON was subjected to the RT-PCR reaction using two oligonucleotides derived from rat PRL cDNA. An amplification product of $388 \mathrm{bp}$ was generated in both the PVN and SON of all experimental groups (Figs 1 and 2). As expected from previous work (Clapp et al. 1994), the size of this product was consistent with the size expected for the amplification of the full-length $23 \mathrm{kDa}$ PRL mRNA and identical to that amplified in the anterior pituitary positive control. No signal was detected in the absence of RT (negative control). 

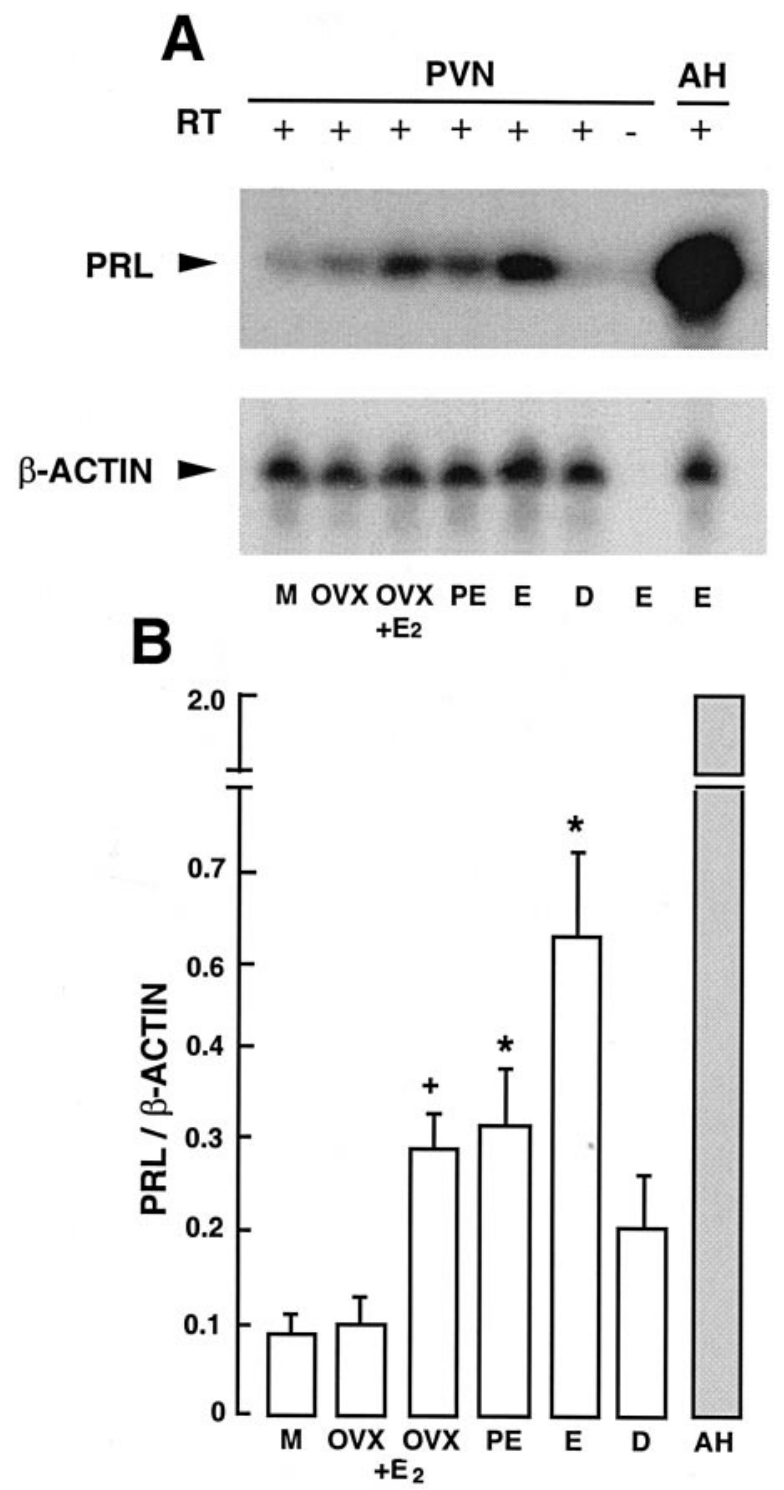

Figure 1 RT-PCR analysis of PRL mRNA in isolated PVN of male $(\mathrm{M}), \mathrm{OVX}$, estradiol-treated $\mathrm{OVX}\left(\mathrm{OVX}+\mathrm{E}_{2}\right)$ rats and of rats at various stages of the estrous cycle. Cycling females were killed at the proestrous (PE), estrous (E) and diestrous II (D) phases of the cycle. (A) Southern blot of PCR products from the PVN and the anterior hypophysis $(\mathrm{AH})$ in the presence or absence of RT. The PCR products for PRL and for $\beta$-actin are 388 and $876 \mathrm{bp}$ respectively. (B) Ratio of PRL to $\beta$-actin RT-PCR products from three independent experiments expressed as means \pm S.E.M. Data were quantitated by densitometry. $+P<0 \cdot 05$ vs OVX rats. ${ }^{*} P<0 \cdot 05$ vs male rats.

The amplification of the $388 \mathrm{bp}$ product was corrected for the efficiency of the reverse transcription reaction by the amplification of $\beta$-actin mRNA, so that changes in amplification signal among groups would reflect differences in the expression of the PRL transcript. However, caution is emphasized even for this semi-quantitative

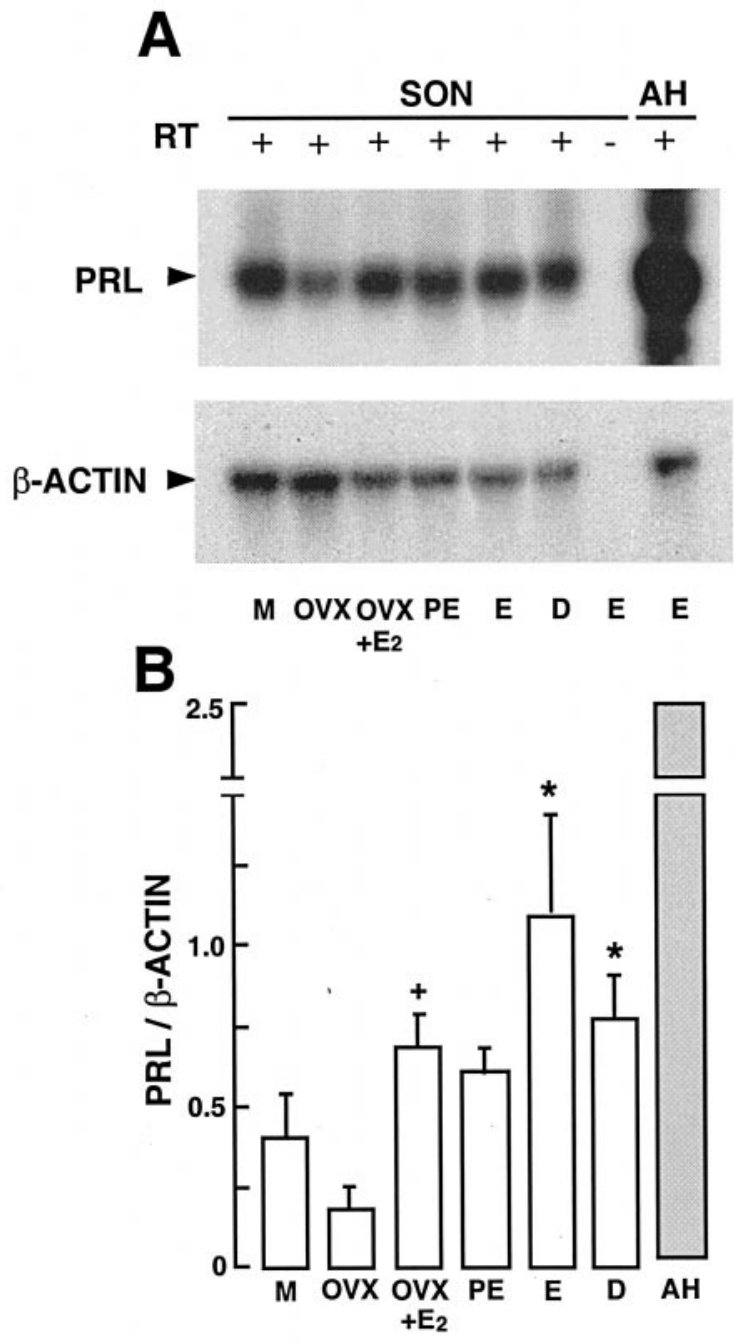

Figure 2 RT-PCR analysis of PRL mRNA in isolated SON of male $(\mathrm{M}), \mathrm{OVX}$, estradiol-treated OVX $\left(\mathrm{OVX}+\mathrm{E}_{2}\right)$ rats and of rats at various stages of the estrous cycle. Cycling females were killed at the proestrous (PE), estrous (E) and diestrous II (D) phases of the cycle. (A) Southern blot of PCR products from the SON and the anterior hypophysis $(\mathrm{AH})$ in the presence or absence of RT.

The PCR products for PRL and for $\beta$-actin are 388 and $876 \mathrm{bp}$ respectively. (B) Ratio of PRL to $\beta$-actin RT-PCR products from three independent experiments expressed as means \pm S.E.M. Data were quantitated by densitometry. $+P<0.05$ vs OVX rats. ${ }^{*} P<0.05$ vs male rats.

interpretation of RT-PCR data. Figure 1 shows representative Southern blots for PRL and $\beta$-actin transcripts amplified from the same PVN RNA sample, as well as the densitometry quantitation of these PCR products from three independent experiments. A higher signal was observed for the PRL transcript in PVNs from cycling females than male rats, with these differences being statistically significant both at proestrus and estrus. Also the 

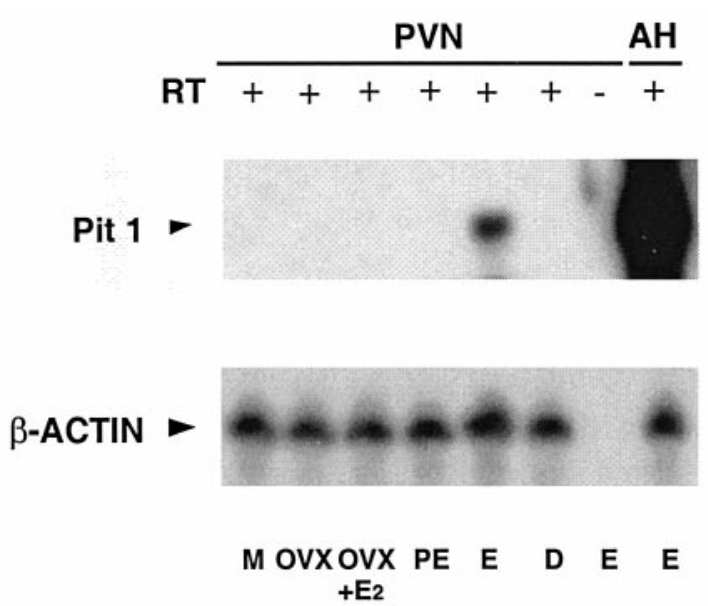

Figure 3 RT-PCR analysis of Pit-1 mRNA in isolated PVN of male (M), OVX, estradiol-treated OVX $\left(\mathrm{OVX}+\mathrm{E}_{2}\right)$ rats and of rats at various stages of the estrous cycle. Cycling females were killed at the proestrous (PE), estrous (E) and diestrous II (D) phases of the cycle. Southern blot of PCR products from the PVN and the anterior hypophysis $(\mathrm{AH})$ in the presence or absence of RT. The PCR products for PRL and for $\beta$-actin are 701 and $876 \mathrm{bp}$ respectively.

PVN PRL mRNA level was significantly higher in OVX/estradiol-treated than in OVX rats (Fig. 1).

Similar changes were observed for the PRL transcript in the SON (Fig. 2). Differences were statistically significant at estrous and diestrous phases of the cycle. Also for the $\mathrm{SON}$, a higher PRL mRNA amplification signal was detected in OVX/estradiol-treated rats than in OVX controls (Fig. 2).

\section{Pit-1 mRNA}

To investigate whether Pit-1, a transcription factor relevant to estrogen regulation of PRL gene expression, is present in the hypothalamo-neurohypophyseal system, PVN total RNA was subjected to RT-PCR using oligonucleotides derived from Pit-1 cDNA. An amplification product of $701 \mathrm{bp}$ was detected in the PVN of estrus rats (Fig. 3). The size of this transcript is similar to that expected for the Pit-1 mRNA and to that amplified from the anterior hypophysis positive control. However, all other samples from PVN were negative, in spite of similar amplification efficiency (Fig. 3).

\section{PRLs}

PRL proteins in neurohypophyseal extracts from individual rats were analyzed by Western blots probed with a $16 \mathrm{kDa}$ PRL antiserum (Figs 4 and 5). As previously reported, neurohypophyseal PRL-like antigens were associated with proteins of 23 and $14 \mathrm{kDa}$, previously shown to specifically react with both polyclonal and

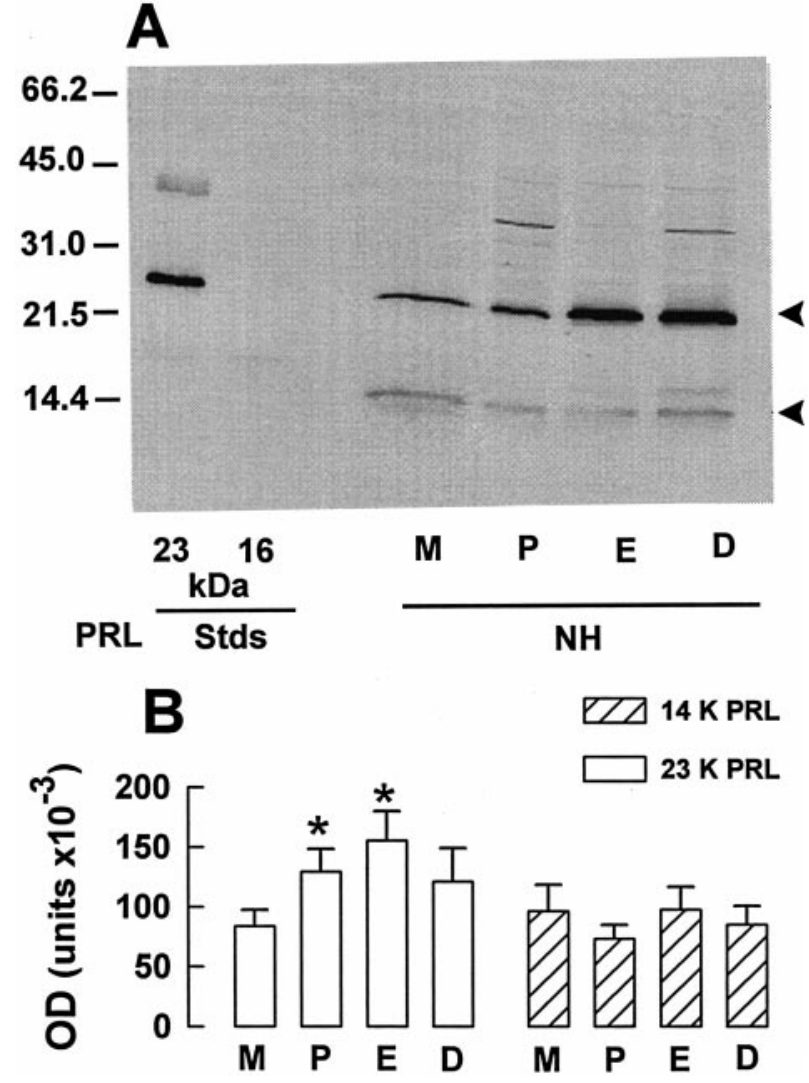

Figure 4 Western blot analysis of neurohypophyseal $(\mathrm{NH})$ extracts of male (M) rats and of rats at various stages of the estrous cycle. Cycling females were killed at the proestrous $(P)$, estrous $(E)$ and diestrous II (D) phases of the cycle. (A) Representative Western blot probed with an antiserum to $16 \mathrm{kDa}$ PRL $(1: 500)$ resolved under reducing conditions. Arrows indicate the migration positions of 23 and $14 \mathrm{kDa}$ PRLs. Molecular mass markers (kDa) are indicated at the left. (B) Densitometric values (optical density; OD) of neurohypophyseal 23 and 14 kDa PRLs from five independent experiments expressed as means \pm S.E.M. ${ }^{*} P<0 \cdot 05$ vs male rats.

monoclonal PRL-directed antibodies (López-Gómez et al. 1995). Identity of $14 \mathrm{kDa}$ PRL, distinct from $16 \mathrm{kDa}$ PRL, has been further established by the addition of $16 \mathrm{kDa}$ PRL standard to neurohypophyseal extracts and the finding in the mixture of two bands, one co-migrating with the $16 \mathrm{kDa}$ PRL standard and the other with the $14 \mathrm{kDa}$ immunoreactive protein (Clapp et al. 1994). Because protein concentrations in neurohypophyseal extracts were normalized among samples, and the linearity of the Western blots clearly established, differences in band intensities were indicative of variations in the respective PRLs concentrations throughout the cycle. The $23 \mathrm{kDa}$ immunoreactive protein showed a higher concentration in neurohypophyses from female cycling rats when compared with male rats (Fig. 4). Also the $23 \mathrm{kDa}$ protein was higher in the neurohypophyses of OVX/estradiol-treated vs OVX rats or prepuberal rats (Fig. 5). Densitometric 

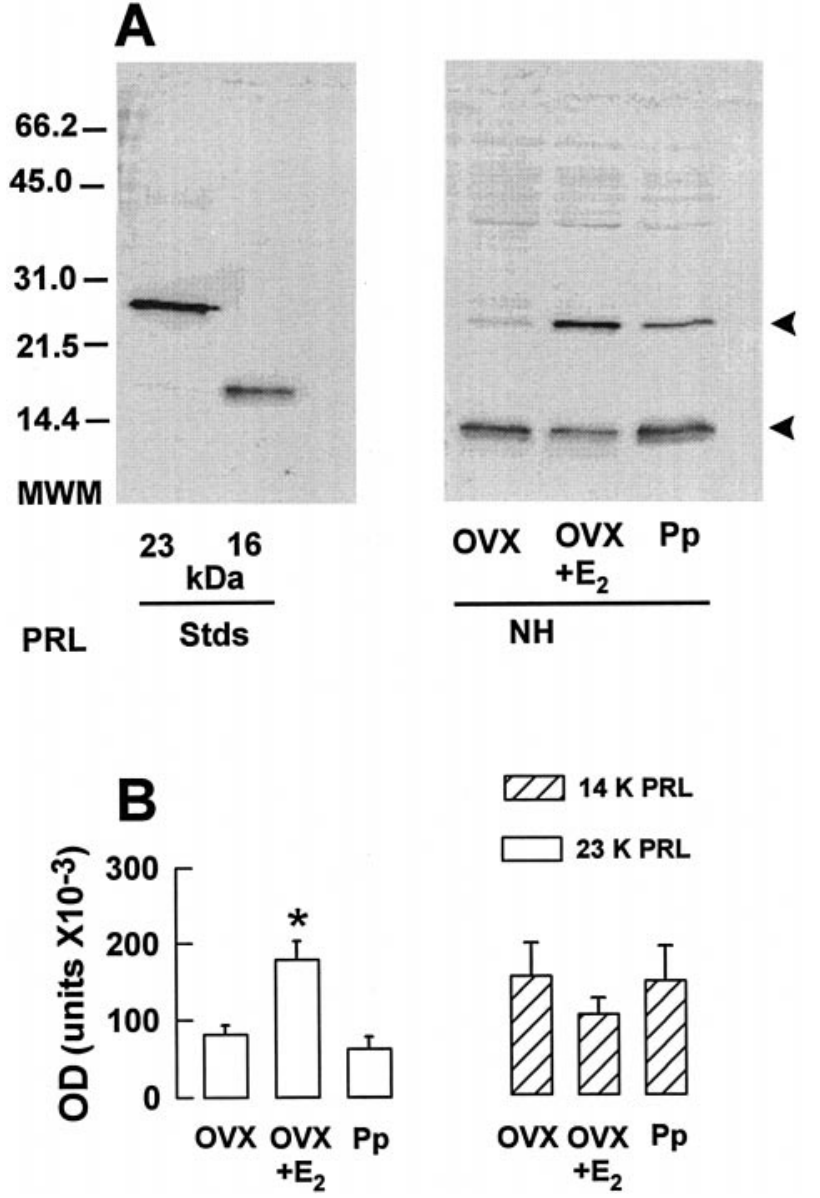

Figure 5 Western blot analysis of neurohypophyseal $(\mathrm{NH})$ extracts of OVX, estradiol-treated OVX $\left(\mathrm{OVX}+\mathrm{E}_{2}\right)$ and female prepuberal (Pp) rats. (A) Representative Western blot probed with an antiserum to $16 \mathrm{kDa}$ PRL (1:500) resolved under reducing conditions. Arrows indicate the migration positions of 23 and 14 kDa PRLs. Molecular mass markers (MWM; kDa) are indicated at the left. (B) Densitometric values (optical density; OD) of neurohypophyseal 23 and $14 \mathrm{kDa}$ PRLs from seven independent experiments expressed as means \pm S.E.M. ${ }^{*} P<0.05$ vs OVX and Pp rats.

analysis of the $23 \mathrm{kDa}$ immunoreactive protein from five and seven independent experiments showed that differences were statistically significant at proestrus and estrus and after estrogen treatment $(P<0 \cdot 05)$ (Figs $4 \mathrm{~B}$ and $5 \mathrm{~B}$ ). Conversely, the concentration of the $14 \mathrm{kDa}$ PRLimmunoreactive protein did not change between male and female cycling rats (Fig. 4), nor among OVX/estradioltreated rats vs the OVX or prepuberal controls (Fig. 5).

\section{PRL-cleaving activity}

An in vitro assay using endogenous PRL-cleaving enzymes was used to determine putative effects of estrogen on PRL proteolytical activity within neurohypophyseal tissue.
These enzymes cleave $23 \mathrm{kDa} \mathrm{PRL}$ around residues 145 and 149, and thus generate a two-chain molecule joined by a disulfide bond (cleaved PRL; Baldocchi et al. (1993)). Reduction of cleaved PRL yields 16 and $7 \mathrm{kDa}$ fragments. The PRL fragment found naturally in, and the one secreted by, the hypothalamo-neurohypophyseal system has an apparent molecular mass of $14 \mathrm{kDa}$ (Clapp et al. 1994, Torner et al. 1995). It remains to be determined whether this fragment corresponds to a further-processed product of $16 \mathrm{kDa}$ PRL or derives by an independent proteolytical pathway. While the molecular structure of $16 \mathrm{kDa}$ PRL is basically known (corresponding to $\mathrm{N}$-terminal residues $1-145$ of $23 \mathrm{kDa}$ PRL (Baldocchi et al. 1993)), that of $14 \mathrm{kDa}$ PRL has not been established. The possibility that $16 \mathrm{kDa} \mathrm{PRL}$ is an intermediate product in $14 \mathrm{kDa}$ production implies certain structural identity between 14 and $16 \mathrm{kDa}$ PRLs. Indeed, the two PRL fragments share immunoreactive and biological determinants (López-Gómez et al. 1995). They are both recognized by antibodies raised against the $\mathrm{N}$ - but not those raised against the C-terminal of $23 \mathrm{kDa}$ PRL. Likewise they both exert a biological action not shared by the parental molecule (Clapp et al. 1994, López-Gómez et al. 1995).

According to above considerations, the enzymatic PRLcleaving activity of neurohypophyseal extracts was compared between OVX and OVX/estradiol-treated rats (Fig. 6). The same amount of $23 \mathrm{kDa}$ PRL standard was incubated with three different protein concentrations from the respective tissue extracts. The three protein concentrations used fall within the linear range of the assay, allowing detection of estrogen effects in any direction. As reported, the PRL-cleaving activity was determined on reducing PAGE-SDS gels by measuring both the disappearance of the $23 \mathrm{kDa}$ PRL band and the concomitant appearance of PRL fragments (Clapp et al. 1987). Less $23 \mathrm{kDa}$ PRL remained and more 16 and $7 \mathrm{kDa}$ PRLs were produced after incubation with neurohypophyseal extracts from OVX rats than from OVX/estradiol-treated animals (Fig. 6). Densitometric analysis of similar gels from three independent experiments found these differences to be statistically significant $(P<0 \cdot 05)$ only at extract protein concentrations of 0.1 and $0.5 \mu \mathrm{g}$ for the $23 \mathrm{kDa}$ and the $16 \mathrm{kDa}$ PRL respectively (Fig. 6B). Because these determinations were performed in OVX animals, the possible involvement of progesterone remains to be determined.

\section{Discussion}

The present study examined changes in the expression of the PRL gene in the hypothalamo-neurohypophyseal system throughout the estrous cycle and in response to estrogen treatment. The results are consistent with estrogens affecting the PRL mRNA levels as well as the concentration and proteolysis of PRL at this site. 

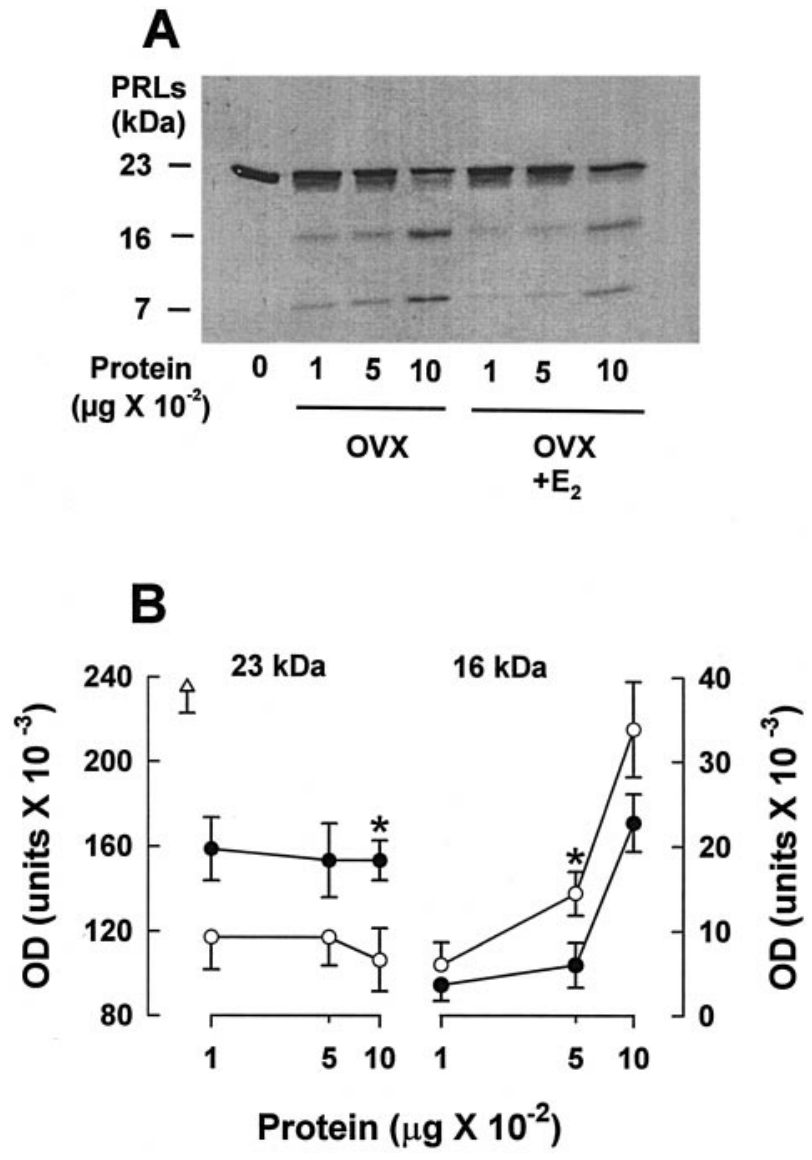

Figure 6 Comparison of PRL-cleaving activity of neurohypophyseal extracts from OVX and estradiol-treated OVX $\left(\mathrm{OVX}+\mathrm{E}_{2}\right)$ rats. (A) Representative Coomassie-stained reduced gel of samples in which the PRL standard (NIH-B6) was incubated with different amounts of protein from neurohypophyseal extracts. The migration positions of 23, 16 and $7 \mathrm{kDa}$ PRLs are indicated at the left.

(B) Densitometric values (optical density; OD) of 23 and $16 \mathrm{kDa}$ PRL of samples in which the PRL standard was incubated in the absence $(\triangle)$ or presence of different protein concentrations from neurohypophyseal extracts of $\mathrm{OVX}(\mathrm{O})$ or $\mathrm{OVX}+\mathrm{E}_{2}(\mathbf{O})$ rats. Values are means \pm S.E.M. from three independent experiments. ${ }^{*} P<0.05$ vs the respective protein concentration.

RT-PCR confirmed and extended previous findings by showing the expression of PRL mRNA in the PVN, as previously reported (Clapp et al. 1994), but also in the SON. Expression of PRL mRNA at both sites correlates with the presence of immunoreactive PRLs in magnocellular neurons from both hypothalamic nuclei (Clapp et al. 1994, Mejía et al. 1997). In the PVN and SON, PRL mRNA levels appeared to be associated with the hormonal status of the animals. An apparently stronger PRL mRNA signal was detected in cycling females than in males, with the highest value being reached at estrus. These changes are similar to those described for PRL message in the anterior pituitary gland, where it is known that the proestrous-estrous surge in PRL mRNA is determined by the increase in circulating estrogen that occurs between diestrus and proestrus (Haisenleder et al. 1989). The possibility that the apparent proestrous-estrous increase in PRL message observed in the PVN, and at estrus in the SON, could also be estrogen induced, is supported by the finding that estrogen administration to OVX rats resulted in a likely increase in the PRL mRNA signal in both nuclei.

A stimulatory effect of estrogen on PRL gene expression in the PVN and SON is not unexpected. Estrogen is a regulator of anterior pituitary PRL, but also of brain PRL (Ben-Jonathan et al. 1996). It increases PRL synthesis and PRL mRNA levels in the hypothalamus and other brain regions of hypophysectomized rats (DeVito et al. 1991, 1992). Also, hypothalamic PRL levels are higher in female than male rats, and are reduced after hypophysectomy in females only, presumably due to low estrogen levels (DeVito 1988). On the other hand, evidence has been provided to indicate that the magnocellular neurosecretory system is regulated by estrogen. Estrogens have been shown to stimulate the release of vasopressin and oxytocin (Slowsky et al. 1979, Yamaguchi et al. 1979, Wang et al. 1995) and the pituitary levels of both hormones have been reported to vary over the course of the estrous cycle or in response to estrogen treatment (Crowley et al. 1978). There is also evidence that estrogen influences oxytocin and vasopressin gene expression in the hypothalamus of osmotically stimulated and lactating rats (Crowley \& Amico 1993, Crowley et al. 1993), and a functional estrogen response element has been located on the promoter region of the oxytocin gene (Mohr \& Schmitz 1991). Furthermore, it has been shown that estrogen enhances the expression of peptides known to coexist with vasopressin in the same magnocellular neuron (Levin \& Sawchenko 1993), a result that correlates with our present findings, since PRLs colocalize with vasopressin in magnocellular neurons from both the PVN and SON (Mejía et al. 1997).

Estrogens regulate the expression of PRL in the anterior pituitary gland by binding to the estrogen response element in the $5^{\prime}$ flanking region of the PRL gene (Maurer et al. 1990). To exert their action, estrogens require multiple binding sites of a POU homeodomain Pit-1 transcriptional factor (Day et al. 1990, Nowakowski \& Maurer 1994). Although Pit-1 has been claimed to be a pivotal regulator for PRL gene expression, alternative Pit-1 transactivating mechanisms also exist. Evidence has been provided that even in the absence of Pit-1, the rat anterior pituitary PRL promoter may be significantly induced by estrogen (Gellersen et al. 1995), and that factors other than Pit-1 may interact with Pit-1 binding sites and activate transcription (Howard \& Maurer 1995). Furthermore, the expression of the PRL gene by some extra-anterior pituitary tissues involves an alternative promoter that is not Pit-1 activated (Gellersen et al. 1994). 
Our present findings suggest that expression of the PRL gene by the hypothalamo-neurohypophyseal system may occur via both Pit-1-dependent and Pit-1-independent mechanisms. Expression of Pit-1 mRNA was detected by RT-PCR in the PVN of estrous rats, but not of other cycling females or male rats. Detection of Pit- 1 mRNA in the PVN during estrus coincides with previous suggestion that both Pit-1 and the estrogen receptor are required for the effect of estrogens on PRL gene expression (Gellersen et al. 1994, Nowakowski \& Maurer 1994). However, all other experimental groups, including that after estrogen administration, were devoid of Pit-1 message. The discrepancy between detection of Pit-1 during estrus but not after estrogen treatment in spite of the high levels of PRL mRNA is not yet understood, but suggests that different transactivating mechanisms, other than Pit-1, are mediating estrogen action on PRL gene expression at this site. Complexity is added by the fact that magnocellular neurons of the PVN and SON appear to contain different types of estrogen receptors. The 'original' estrogen receptor, now known as ER $\alpha$, has been located in few of these neurons which, in turn, preferentially locate the newly identified ER $\beta$ (Simerly et al. 1990, Alves et al. 1998). Although both ERs are capable of activating gene transcription by binding to an estrogen response element (Tremblay et al. 1997), recent evidence showed that ER $\alpha$ and ER $\beta$ mediated estrogen-induced activation and inhibition of transcription respectively (Paech et al. 1997). A differential activation of either ER within the magnocellular neurosecretory system could contribute to a different mechanism operating PRL gene expression at this site. It should be noted that a similar disparity between expression of PRL gene and Pit-1 message has been noted previously in the male rat hypothalamus (Emanuele et al. 1992), and this is a common place for most extra-pituitary PRL-producing sites (Ben-Jonathan et al. 1996).

The translation of PRL mRNA in the hypothalamoneurohypophyseal system has been supported by the presence of immunoreactive and biologically active PRLs in magnocellular neurons of the PVN, SON and in their neurohypophyseal endings (Clapp et al. 1994, LópezGómez et al. 1995, Mejía et al. 1997). These PRLs include variants of 23 and $14 \mathrm{kDa}$ that have been determined both in intact and in hypophysectomized rats (Clapp et al. 1994, Torner et al. 1995). Here we show that the levels of both neurohypophyseal PRL variants display a distinct pattern throughout the estrous cycle and in response to estrogen treatment. The concentration of the neurohypophyseal $23 \mathrm{kDa}$ variant was significantly higher during the proestrous-estrous phases of the cycle and in OVX rats after treatment with estrogen. These changes in neurohypophyseal $23 \mathrm{kDa}$ PRL parallel those of PRL mRNA in the PVN and SON, and therefore substantiate the possibility that the increases in PRL mRNA levels occurring in the hypothalamo-neurohypophyseal system during the estrous cycle result in higher protein production.
In contrast to the $23 \mathrm{kDa} \mathrm{PRL}$, the neurohypophyseal $14 \mathrm{kDa}$ PRL did not change throughout the cycle, nor in response to estrogen treatment. The reason for this lack of change is not clear. In part, it may be explained by the suggestion that proteolysis of PRL could be regulated during the estrous cycle. Fourteen kilodalton PRL appears to be generated not by an alternative splicing but by the proteolysis and reduction of neurohypophyseal $23 \mathrm{kDa}$ PRL (Clapp et al. 1994). No alternatively spliced PRL mRNA is expressed in the PVN or SON, and the enzymes able to cleave $23 \mathrm{kDa}$ PRL have been shown to be active in the hypothalamo-neurohypophyseal system (Clapp et al. 1994). Because $23 \mathrm{kDa}$ PRL may function as a precursor for $14 \mathrm{kDa} P R L$, the increase in the levels of the parent molecule should favor the generation of the fragment through enzymatic proteolysis, unless such processing is being held under control. Here we show that the proestrus-estrus increase in $23 \mathrm{kDa} \mathrm{PRL}$ is not followed by concomitant higher levels of $14 \mathrm{kDa}$ PRL, and that in contrast to the stimulation on neurohypophyseal $23 \mathrm{kDa}$ PRL, treatment with estrogen was associated with a non-significant decline in neurohypophyseal $14 \mathrm{kDa}$ PRL.

The possibility that the lack of correlation between PRL variant levels, during the proestrous-estrous phases of the cycle, could be due to an inhibition of the proteolysis of $23 \mathrm{kDa}$ PRL into the $14 \mathrm{kDa}$ fragment is not unlikely. The present findings show that estrogen reduces the activity of neurohypophyseal enzymes, able to cleave $23 \mathrm{kDa}$ PRL into a $16 \mathrm{kDa}$ PRL fragment, a form of PRL that shares similar antigenic and biological determinants with neurohypophyseal $14 \mathrm{kDa}$ PRL (Clapp et al. 1994, López-Gómez et al. 1995, Mejía et al. 1997). Furthermore, this effect of estrogen on PRL-cleaving activity is not entirely unexpected. The enzyme responsible for the PRL cleavage appears to be a cathepsin D-like protease (Baldocchi et al. 1993) and estrogen has been shown to regulate the activity of cathepsin $\mathrm{D}$, but in an opposite direction. Thus, estrogen stimulates the amount and activity of cathepsin D in the rat uterus (Elangovan \& Moulton 1980) and the synthesis of a pro-cathepsin D and its mRNA in breast tumor cells (Westley \& May 1987). Furthermore, the role of estrogen as a regulator of PRL proteases is not new. The production of a $22 \mathrm{kDa} \mathrm{PRL}$ variant generated by kallikrein, a trypsin-like serine protease, is stimulated by estrogens (Powers 1986, Powers \& Hatala 1990).

Overall, the present results provide evidence for complex, and differential regulation by estrogen of PRLs coexisting in the two major cellular components of the hypothalamo-neurohypophyseal system. The functional implications of these effects are unclear, but results in normally cycling animals support the view that such influences may participate in posterior pituitary PRLs output under normal physiological conditions. Likewise, the role of neurohypophyseal PRLs is still a matter of 
speculation. Open possibilities include local neurotrophic actions and endocrine effects on distant targets. Our preliminary data show that both $23 \mathrm{kDa}$ PRL and the $16 \mathrm{kDa}$ fragment stimulate the release of vasopressin by hypothalamo-neurohypophyseal explants (S Mejía \& C Clapp, unpublished observations). Because PRLs colocalize with vasopressin in the same cells (Mejía et al. 1997), and PRL receptors have been detected in magnocellular neurons of the hypothalamo-neurohypophyseal system (Roky et al. 1996), a PRL autocrine action on vasopressin secretion is a likely possibility.

\section{Acknowledgements}

We thank Rafael Favila for his expert technical assistance and the National Hormone and Pituitary Program, National Institute of Diabetes and Digestive and Kidney Diseases for their generous gift of rat PRL. This work was supported by Grants IN201895 from the National University of Mexico, 3662P-N9607 from the National Council of Science and Technology of Mexico and 75197-554801 from the Howard Hughes Medical Institute.

\section{References}

Alves SE, Lopez V, McEwen BS \& Weiland NG 1998 Differential colocalization of estrogen receptor $\beta(\operatorname{Er} \beta)$ with oxytocin and vasopressin in the paraventricular and supraoptic nuclei of the female rat brain: An immunocytochemical study. Proceedings of the National Academy of Sciences of the USA 95 3281-3286.

Baldocchi RA, Tan L, King DS \& Nicoll CS 1993 Mass spectrometric analysis of the fragments produced by cleavage and reduction of rat prolactin: evidence that the cleaving enzyme is cathepsin D. Endocrinology 133 935-938.

Ben-Jonathan N, Mershon JL, Allen DL \& Steinmetz RW 1996 Extrapituitary prolactin: distribution, regulation, functions, and clinical aspects. Endocrine Reviews 17 639-669.

Brownstein MJ \& Mezey E 1986 Multiple chemical messengers in hypothalamic magnocellular neurons. In Progress in Brain Research, vol 68, pp 161-168. Eds T Hökfelt, K Fuxe \& B Pernow. Basel: Elsevier Scientific Publishers.

Chomczynski P \& Sacchi N 1987 Single-step method of RNA isolation by acid guanidinium thiocyanate-phenol-chloroform extraction. Analytical Biochemistry 162 156-159.

Clapp C 1987 Analysis of the proteolytic cleavage of prolactin by the mammary gland and liver of the rat: characterization of the cleaved and $16 \mathrm{~K}$ forms. Endocrinology 121 2055-2064.

Clapp C, Sears PS \& Nicoll CS 1989 Binding studies with intact rat prolactin and a $16 \mathrm{~K}$ fragment of the hormone. Endocrinology 125 1054-1059.

Clapp C, Torner L, Gutiérrez-Ospina G, Alcántara E, López-Gómez FJ, Nagano M, Kelly PA, Mejía S, Morales MA \& Martínez de la Escalera G 1994 The prolactin gene is expressed in the hypothalamic-neurohypophyseal system and the protein is processed into a $14-\mathrm{kDa}$ fragment with activity like $16-\mathrm{kDa}$ prolactin. Proceedings of the National Academy of Sciences of the USA 91 10384-10388.

Crenshaw EB, Kalla K, Simmons DM, Swanson LW \& Rosenfeld MG 1989 Cell-specific expression of the prolactin gene in transgenic mice is controlled by synergistic interactions between by promoter and enhancer elements. Genes and Development $\mathbf{3}$ 959-972.

Crowley RS \& Amico JA 1993 Gonadal steroid modulation of oxytocin mRNA expression in the hypothalamus of the osmotically stimulated rat. Endocrinology 133 2711-2718.

Crowley WR, O'Donohye TL, George JM \& Jacobowitz DM 1978 Changes in pituitary oxytocin and vasopressin during the estrous cycle and after ovarian hormones: evidence for mediation by norepinephrine. Life Sciences 23 2579-2586.

Crowley RS, Insel TR, O'Keefe JA \& Amico JA 1993 Cytoplasmic oxytocin and vasopressin gene transcripts decline postpartum in the hypothalamus of the lactating rat. Endocrinology 133 2704-2710.

Day RN, Kolke S, Sakai M, Muramatsu M \& Maurer RA 1990 Both Pit-1 and the estrogen receptor are required for estrogen responsiveness of the rat prolactin gene. Molecular Endocrinology 4 1964-1971.

DeVito WJ 1988 Distribution of immunoreactive prolactin in the male and female rat brain: effects of hypophysectomy and intraventricular administration of colchicine. Neuroendocrinology 47 284-289.

DeVito WJ, Stone S \& Avakian C 1991 Stimulation of hypothalamic prolactin release by veratridine and angiotensin in the female rat: effect of ovariectomy and estradiol administration. Neuroendocrinology 54 391-398.

DeVito WJ, Avakian C, Stone S \& Ace C 1992 Estradiol increases prolactin synthesis and prolactin messenger ribonucleic acid in selected brain regions in the hypophysectomized female rat. Endocrinology 131 2154-2160.

Elangovan S \& Moulton BC 1980 Progesterone and estrogen control of rates of synthesis of uterine cathepsin D. Journal of Biological Chemistry 255 7474-7479.

Emanuele NV, Jurgens JK, Halloran MM, Tentler JJ, Lawrence AM \& Kelley MR 1992 The rat prolactin gene is expressed in brain tissue: detection of normal and alternatively spliced prolactin messenger RNA. Molecular Endocrinology 6 35-42.

Feimberg AP \& Vogelstein B 1983 A technique for radiolabeling DNA restriction endonuclease fragments to high specific activity. Analytical Biochemistry 132 6-13.

Gellersen B, Kempf R, Telgmann R \& DiMattia GE 1994 Nonpituitary human prolactin gene transcription is independent of Pit-1 and differentially controlled in lymphocytes and in endometrial stroma. Molecular Endocrinology 8 356-373.

Gellersen B, Kempf R, Telgmann R \& DiMattia GE 1995 Pituitary-type transcription of the human prolactin gene in the absence of pit-1. Molecular Endocrinology 9 887-901.

Haisenleder DJ, Ortolano GA, Ladefeld TD, Zmeili SM \& Marshall JC 1989 Prolactin messenger ribonucleic acid concentrations in 4-day cycling rats and during the prolactin surge. Endocrinology 124 2023-2028.

Hatton GI 1990 Emerging concepts of structure-function dynamics in adult brain: the hypothalamo-neurohypophysial system. Progress in Neurobiology 34 437-504.

Hebert SC, Schafer JA \& Andreoli TE 1981 The effects of antidiuretic hormone $(\mathrm{ADH})$ on solute and water transport in the mammalian nephron. Journal of Membrane Biology 58 1-19.

Howard PW \& Maurer RA 1995 A composite ETs/Pit-1 binding site in the prolactin gene can mediate transcriptional responses to multiple signal transduction pathways. Journal of Biological Chemistry $27020930-20936$.

Ingraham HA, Chen R, Mangalam HJ, Elsholtz HP, Flynn SE, Lin CR, Simmons DM, Swanson L \& Rosenfeld MG 1988 A tissue-specific transcription factor containing a homeodomain specifies a pituitary phenotype. Cell 55 519-529.

Levin MC \& Sawchenko PE 1993 Neuropeptide co-expression in the magnocellular neurosecretory system of the female rat: evidence for differential modulation by estrogen. Neuroscience 54 1001-1018. 
López-Gómez FJ, Torner L, Mejía S, Martínez de la Escalera G \& Clapp C 1995 Immunoreactive prolactins of the neurohypophyseal system display actions characteristic of prolactin and $16 \mathrm{~K}$ prolactin. Endocrine 3 573-579.

Loretz CA \& Bern HA 1982 Prolactin and osmoregulation in vertebrates. Neuroendocrinology 35 632-637.

Maurer RA, Kim KE, Day RN \& Notides AC 1990 Regulation of prolactin gene expression by estradiol. In Molecular Endocrinology and Steroid Hormone Action, pp 159-169. Eds G Sato \& JL Stevens. New York: Alan R Liss.

Meister B 1993 Gene expression and chemical diversity in hypothalamic neurosecretory neurons. Molecular Neurobiology 7 87-110.

Mejía S, Morales MA, Zetina ME, Martínez de la Escalera G \& Clapp C 1997 Immunoreactive prolactin forms colocalize with vasopressin in neurons of the hypothalamic paraventricular and supraoptic nuclei. Neuroendocrinology 66 151-159.

Mohr E \& Schmitz E 1991 Functional characterization of estrogen and glucocorticoid responsive elements in rat oxytocin gene. Molecular Brain Research 9 293-298.

Nelson C, Albert VR, Lu LI-W \& Rosenfeld MG 1988 Activation of cell-specific expression of rat growth hormone and prolactin genes by a common transcription factor. Science 239 1400-1405.

Nowakowski BE \& Maurer RA 1994 Multiple Pit-1-binding sites facilitate estrogen responsiveness of the prolactin gene. Molecular Endocrinology 8 1742-1749.

Paech K, Webb P, Kuiper GJM, Nilsson S, Gustafsson JA, Kushner PJ \& Scanlan TS 1997 Differential ligand activation of estrogen receptors Er $\alpha$ and $\operatorname{Er} \beta$ at AP1 sites. Science 277 1508-1510.

Palkovits M 1983 Punch sampling biopsy technique. Methods in Enzymology 103 369-376.

Powers CA 1986 Anterior pituitary glandular kallikrein: estrogen regulation and trypsin activation. Molecular and Cellular Endocrinology 46 163-174.

Powers CA \& Hatala MA 1990 Prolactin proteolysis by glandular kallikrein: in vitro reaction requirements and cleavage sites, and detection of processed prolactin in vivo. Endocrinology 127 1916-1927.
Roky R, Paut-Pagano L, Goffin V, Kitahama K, Valatx J-L, Kelly PA \& Jouvet M 1996 Distribution of prolactin receptors in the rat forebrain. Immunohistochemical study. Neuroendocrinology 63 422-429.

Simerly RB, Chang C, Miramatsu M \& Swanson LW 1990 Distribution of androgen and estrogen receptor mRNA-containing cells in the rat brain: an in situ hybridization study. Journal of Comparative Neurology 294 76-95.

Slowsky WR, Swan L \& Smith P 1979 Effects of sex steroid hormones on arginine vasopressin in intact and castrated male and female rats. Endocrinology 104 105-108.

Torner L, Mejía S, López-Gómez FJ, Quintanar A, Martínez de la Escalera G \& Clapp C 1995 A 14-kilodalton prolactin-like fragment is secreted by the hypothalamo-neurohypophyseal system of the rat. Endocrinology 136 5454-5460.

Tremblay GB, Tremblay A, Copeland NG, Gilbert DJ, Jenkins NA, Labrie F \& Giguère V 1997 Cloning, chromosomal localization, and functional analysis of the murine estrogen receptor $\beta$. Molecular Endocrinology 11 353-365.

Villar MJ, Meister B, Cortés R, Schalling M, Morris M \& Hökfelt T 1990 Neuropeptide gene expression in hypothalamic magnocellular neurons of normal and hypophysectomized rats: a combined immunohistochemical and in situ hybridization study. Neuroscience 36 181-199.

Wang H, Ward AR \& Morris JF 1995 Oestradiol acutely stimulates exocytosis of oxytocin and vasopressin from dendrites and somata of hypothalamic magnocellular neurons. Neuroscience 68 1179-1188.

Westley BR \& May FEB 1987 Oestrogen regulates cathepsin D mRNA levels in oestrogen responsive human breast tumor cancer cells. Nucleic Acids Research 15 3773-3786.

Yamaguchi K, Akaishi T \& Megoro H 1979 Effects of estrogen treatment on plasma oxytocin and vasopressin in ovariectomized rats. Endocrinologica Japonica 26 197-205.

Received 23 October 1998

Accepted 26 January 1999 